UDC 336.71

DOI: $10.25140 / 2411-5215-2018-1(13)-160-174$

Yadviga Zharii, Yuliia Krasnianska

\title{
DIRECTIONS OF MODERNIZATION OF THE ENVIRONMENTAL PROJECTS IN UKRAINE AND THE FINANCIAL ASPECTS OF THEIR IMPLEMENTATION
}

\author{
Ядвіга Жарій, Юлія Краснянська \\ НАПРЯМИ МОДЕРНІЗАЦЇ̈ ЕКОЛОГІЧНИХ ПРОЕКТІВ В УКРАЇНІ \\ ТА ФІНАНСОВІ АСПЕКТИ ЇХ РЕАЛІЗАЦЇ̈
}

\author{
Ядвига Жарий, Юлия Краснянская \\ НАПРАВЛЕНИЯ МОДЕРНИЗАЦИИ ЭКОЛОГИЧЕСКИХ ПРОЕКТОВ \\ В УКРАИНЕ И ФИНАНСОВЫЕ АСПЕКТЫ ИХ РЕАЛИЗАЦИИ
}

The article analyzes the state of domestic and other waste management in Ukraine and specifies unresolved problems in the waste utilization system. The experience of the European Union member states, which created the established mechanism of separate collection of waste, material and energy recycling, environmentally safe disposal of waste at the constructed landfills is considered. The directions of modernization of the waste recycling system in Ukraine and the financial aspects of their implementation are proposed.

Key words: household waste; waste utilization; separate collection mechanism; material and energy recycling; financial and industrial group.

Fig.: 10. References: 28.

У статті досліджено стан поводження з побутовими й іншими відходами в Украйні та виконано аналіз невирішених проблем у системі утилізації відходів. Розглянуто досвід держсв - членів Свропейського Союзу, які створили налагоджений механізм роздільного збирання відходів, матеріального та енергетичного рециклінгу, екологічно безпечного захоронення відходів на сконструйованих полігонах. Запропоновано напрями модернізаиії системи утилізачиї відходів в Україні та фінансові аспекти їх реалізації.

Ключові слова: побутові відходи; утилізація відходів; механізм роздільного збирання відходів; матеріальний та енергетичний рецииклінг; фінансово-промислова група.

Рис.: 10. Бібл.: 28.

В статье исследовано состояние поведения с бытовыми и другими отходами в Украине и выполнен анализ нерешенных проблем в системе утилизации отходов. Рассмотрен опыт стран - членов Европейского Союза, которыми создан налаженный механизм раздельного сбора отходов, материальный и энергетический рециклинг, экологически безопасного захоронения отходов на сконструированных полигонах. Предложены направления модернизащии системы утилизации отходов в Украине и финансовые аспекты их реализации.

Ключевые слова: бытовые отходы; утилизация отходов; механизм раздельного сбора отходов; материальный и энергетический рещиклинг; финансово-промысловая группа.

Pис.: 10. Библ.: 28.

JEL Classification: G29, H49, O57

Target setting. In Ukraine, for a long period of time, "stocks" of household and similar waste were accumulated, and the problems of their utilization for preservation of the environment at the proper level were not solved. There was only mass burning of waste, wastewater from the reservoir or buried waste at the bottom of the earth were created. The results of such actions not only do not allow economically and socially advantageous use of these areas, but also cause serious environmental problems: air pollution and the presence of odors (especially in the summer); reproduction of bacteria - pathogens of various diseases; penetration of harmful elements into groundwater, etc.

During the years of our country's independence, these issues were officially ignored, causing only the interest of activists. Not indifferent citizens of the country created a network of points of reception of certain types of "especially harmful" garbage (for example, batteries, mercury thermometers) with the holding of thematic educational trainings, exhibitions, competitions and other events.

However, in order to dispose of permanently accumulated domestic and other wastes, every country in the world needs to have suitable equipment and technologies for waste recycling to maintain the proper ecological system. For Ukraine, this issue also needs general attention and immediate resolution, as the trend of constant accumulation of wastes is a 
ФІНАНСОВІ РЕСУРСИ: ПРОБЛЕМИ ФОРМУВАННЯ ТА ВИКОРИСТАННЯ

significant gap in the country that has made the decision to integrate with the European Union. By creating an established mechanism for the recycling of household and similar waste, the EU Member States have shown to the world a benchmark example of the possibility of obtaining economic benefits, achieving a positive social effect and preserving the environment at the same time. That is, the formation of such a system in Ukraine is an urgent necessity and an actual problem.

Actual scientific research and issues analysis. Domestic and foreign scientists studied some aspects regarding the treatment of domestic and similar waste recycling systems in Ukraine and in the EU member states, they searched for various ways of their modernization, studied the advantages and disadvantages of various waste recycling systems from the economic, environmental and social point of view. Problems of garbage recycling and utilization in Ukraine are highlighted in scientific works of Pogribny I. [12], Kryvenko S. [10], Poltavets S., Beregelsky A. [14] and others. Ukrainian scientists paid attention to modern possibilities of reforming the sphere of treatment of household and similar waste. Thus, Ignatenko O. considered the legal and economic aspects of the creation and operation of garbage collection, waste recycling, waste incineration plants and disclosed the features of state policy regarding such objects [7]. Shylovych T. highlighted the legislative problems of the development of this sphere, showed their negative economic and environmental impact and ways of transforming problems [17]. The positive economic effect of functioning of the established mechanism of processing solid household waste has been demonstrated in the work of Abramova M. and Osmanov I. [1]. Kharchenko T., Sagaidak Yu., Grabovsky R., Dorosh M., Dudyak R., A. Garg, K. Kim, J. Marchant, R. Smith and others investigated the experience of foreign countries, including EU countries, on the implementation of the system of household waste management $[16 ; 3 ; 21]$.

Uninvestigated parts of general issue defining. Despite a large number of scientific works devoted to the analysis of the state of domestic and similar waste management in Ukraine and the search for ways of transformation, the existing system, which includes the general collection of garbage, its transportation, the creation of dumps, several waste processing and incineration plants, disposal of waste in the lithosphere, for a highly developed state is unacceptable. Such a mechanism, which contradicts the sustainable development of the Ukrainian economy, significantly impedes its integration processes into the EU. It is expedient to comprehensively study this problem, systematize of the experience of the EU member states in solving this issue in the context of individual countries, and identify ways of modernizing the research-based mechanism existing in our country.

Purpose of the article. The purpose of the article is to comprehensively diagnose the current state of domestic and similar waste management in Ukraine, identify key issues, compare key indicators, in particular economic data, with data from EU Member States, study the experience of reforming the industry of these countries in order to develop practical recommendations adapted to Ukrainian realities, justifying the financial aspects of such modernization.

Statement of the main material. In Ukraine, there is a clear tendency to increase the amount of collected household and similar waste (HSW) annually. According to the State Statistics Service of Ukraine in 2016, every inhabitant of the state on average produced 271 $\mathrm{kg}$ of such waste (Fig. 1). The volume of collected HSW per capita in most EU member states is much higher than in Ukraine, due to the growing needs of the population, the full material provision of office buildings and organizations (hospitals, schools), the existence of a perfect system of permanent cleaning of parks. 


\section{ФІНАНСОВІ РЕСУРСИ: ПРОБЛЕМИ ФОРМУВАННЯ ТА ВИКОРИСТАННЯ}

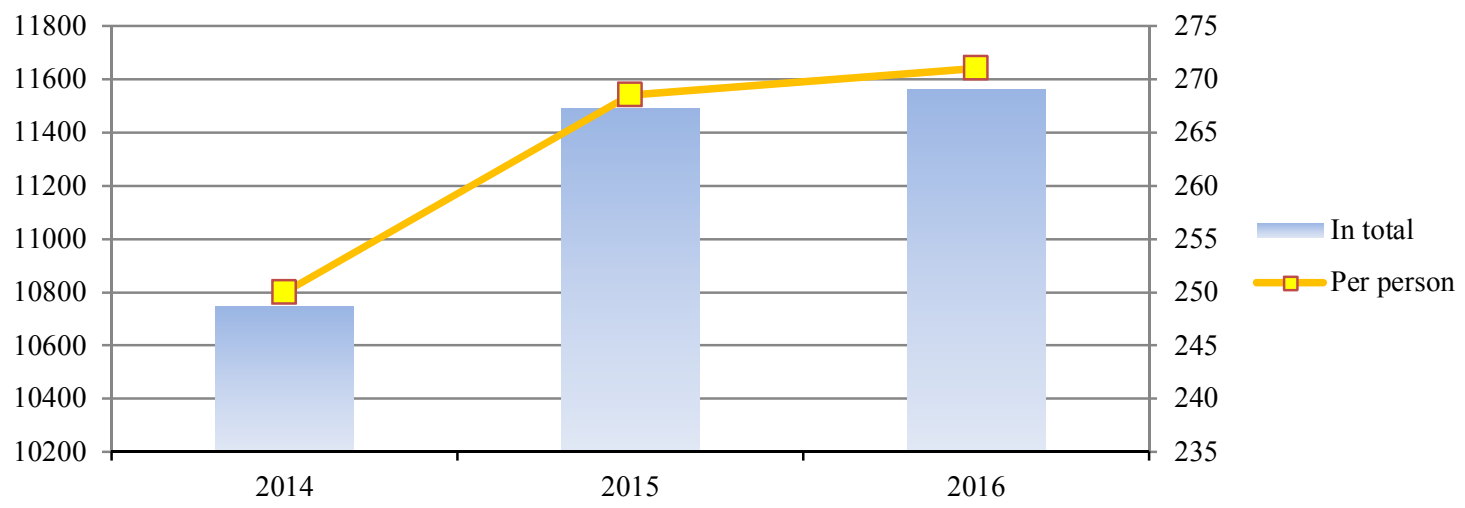

Fig. 1. Dynamics of collected HSW during 2014-2016 (excluding occupied territories and zone of ATO), thousand tons, $\mathrm{kg} /$ person

Source: complied based on [25].

The European community solves the problem of garbage accumulation, not only by creating a well-functioning mechanism for its recycling, but also by popularizing educational activities (trainings, TV programs, leaflets) aimed at reducing the volume of its production. Permanent planning of such campaigns gave the expected positive result: the volume of HSW per capita in the EU in 2000 was $521 \mathrm{~kg}$, in $2010-504 \mathrm{~kg}$, in $2015-476 \mathrm{~kg}$ due to a negative balance in most countries of this community (Fig. 2).

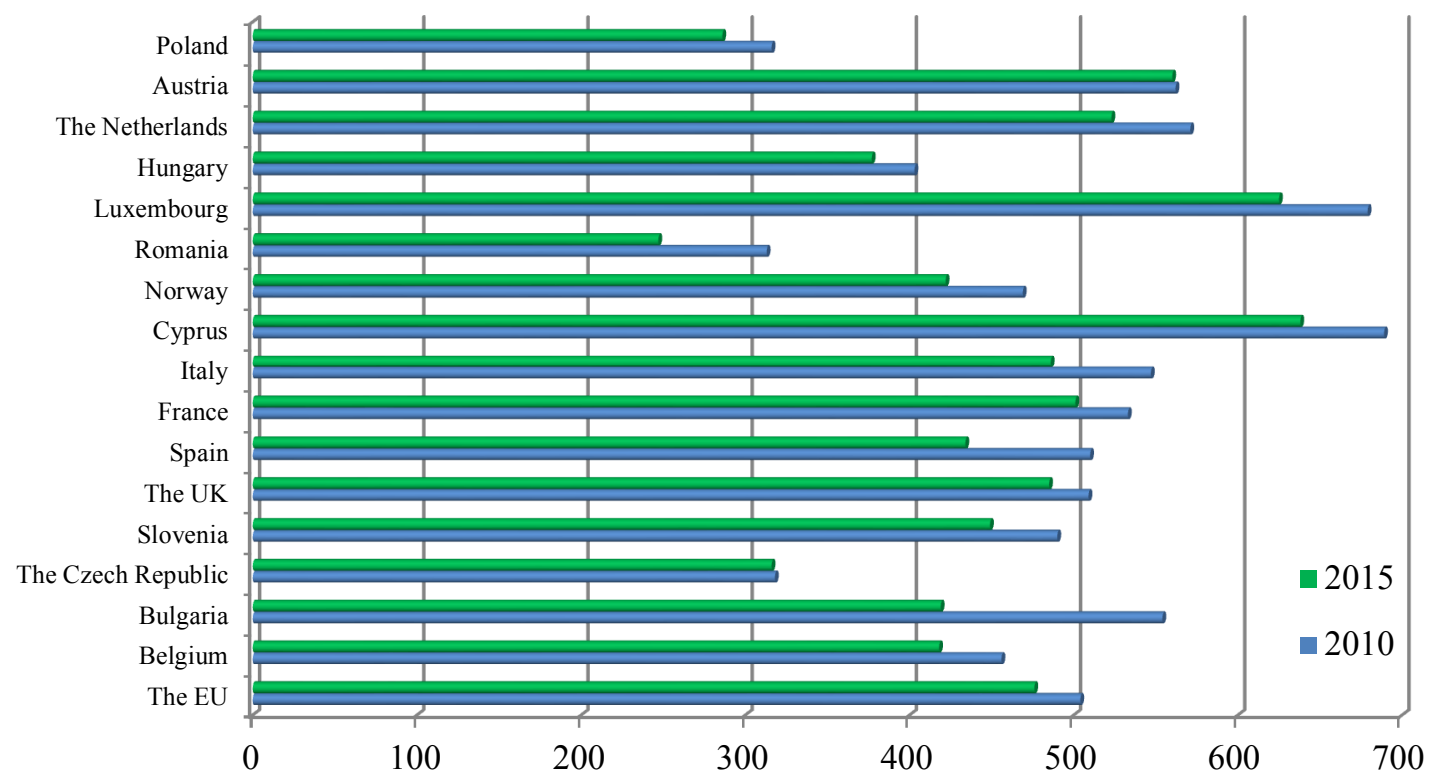

Fig. 2. EU Member States that reduced the amount of PPV, $\mathrm{kg} /$ person

Source: compiled based on [25].

In Ukraine, in 2016, only 6.5 thousand tons $(0.066 \%)$ of collected household rubbish were utilized. Such insignificant value contradicts the conditions of sustainable development of the state, which will become a significant obstacle on the way of Ukraine's integration into the EU. Thanks to the efforts of the EU member states to create a well-established mechanism for the processing of HSW, there is a steady increase in the share of their utilization (Fig. 3), unlike in Ukraine, where the value during the research years 2011-2015 did not exceed $0.72 \%$. 
ФІНАНСОВІ РЕСУРСИ: ПРОБЛЕМИ ФОРМУВАННЯ ТА ВИКОРИСТАННЯ

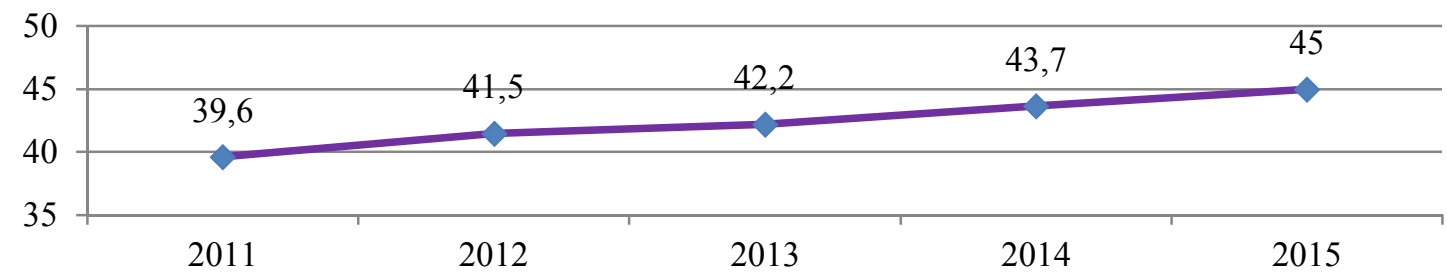

Fig. 3. Dynamics of the share of utilized HSW in the EU during 2011-2015, \%

Source: complied by the author based on [27].

The rate of HSW disposal in the context of individual EU member states is significantly different (Fig. 4). The highest is in the leading countries - founders of the community with a long history of the functioning of the recycling system (Germany, Austria, Slovenia, Belgium), the lowest is in the newly-integrated countries and countries with significant economic problems (Serbia, Montenegro, Malta).

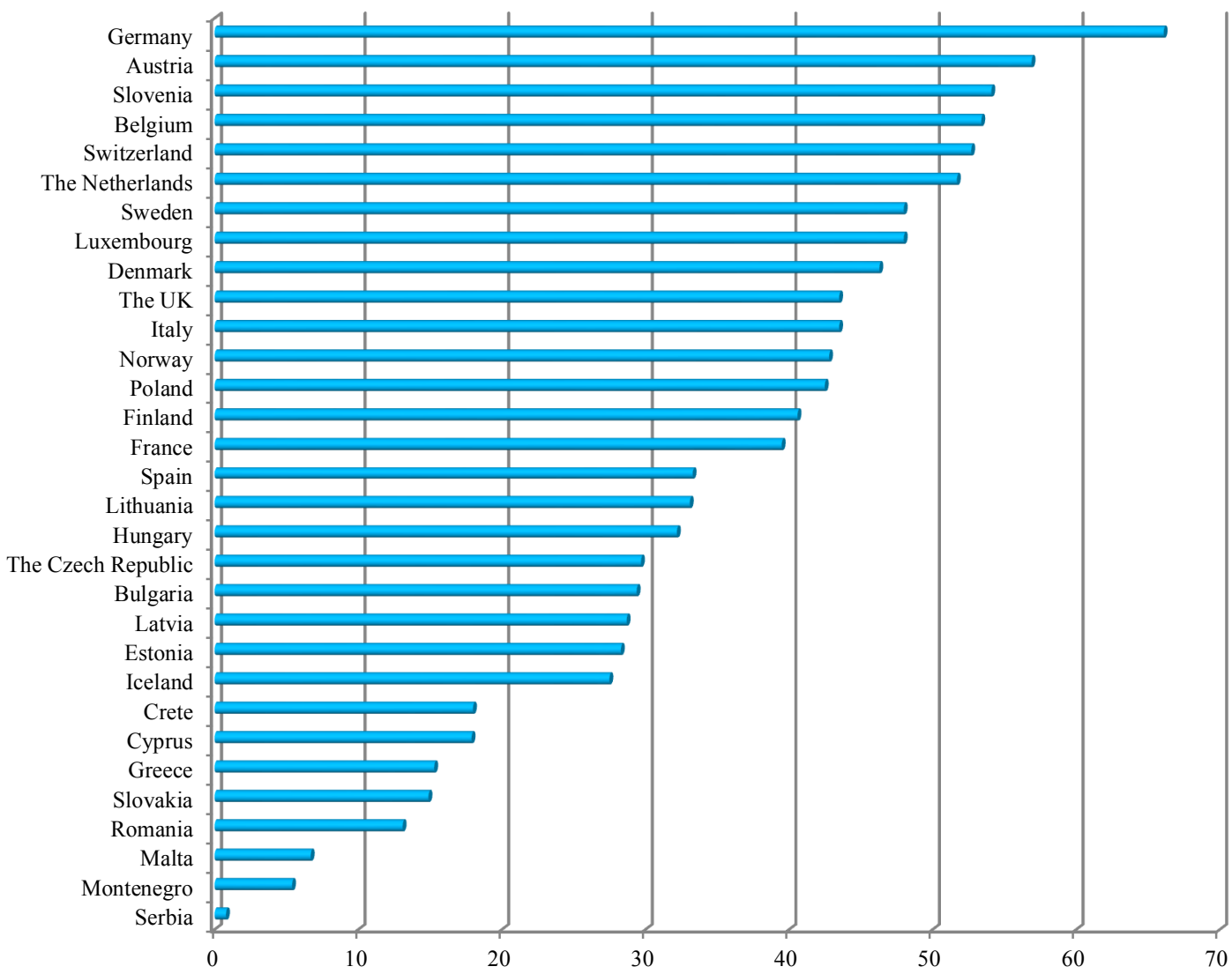

Fig. 4. Share of recycled HSW by EU member states in 2015, \%

Source: complied based on [27].

Garbage utilization involves the material recycling of HSW or the receipt of energy resources through the use of waste as an alternative fuel. Each type of rubbish is subject to appropriate technical and technological processing. Therefore, in order to realize the processing of HSW, there must be a well-established mechanism for their separate collection. According to official data, in the third quarter of 2016 in Ukraine, in 573 settlements $(1.93 \%$ of their total number), there were areas for separate collection of garbage. The share of inhabitants covered by the provision of such a service varied considerably from the perspective of individual settlements (from $2.1 \%$ to $100 \%$ ), only $5.85 \%$ of solid HSW were collected separately from 
ФІНАНСОВІ РЕСУРСИ: ПРОБЛЕМИ ФОРМУВАННЯ ТА ВИКОРИСТАННЯ

the total volume generated in these settlements and $0,058 \%$ of the total collected HSW in 2016 in Ukraine. Without the arrangement of sites for separate garbage collection, according to researches of specialists, in the presence of a high-tech system of its processing, it is possible to remove a maximum of $15 \%$ of useful components, while when sorting -it is about $75 \%$ [9; 8 ; 14]. If the development of the field of rubbing in Ukraine is at an initial stage, then the study of the mechanism of processing of HSW would rather indicate its absence (Fig. 5).

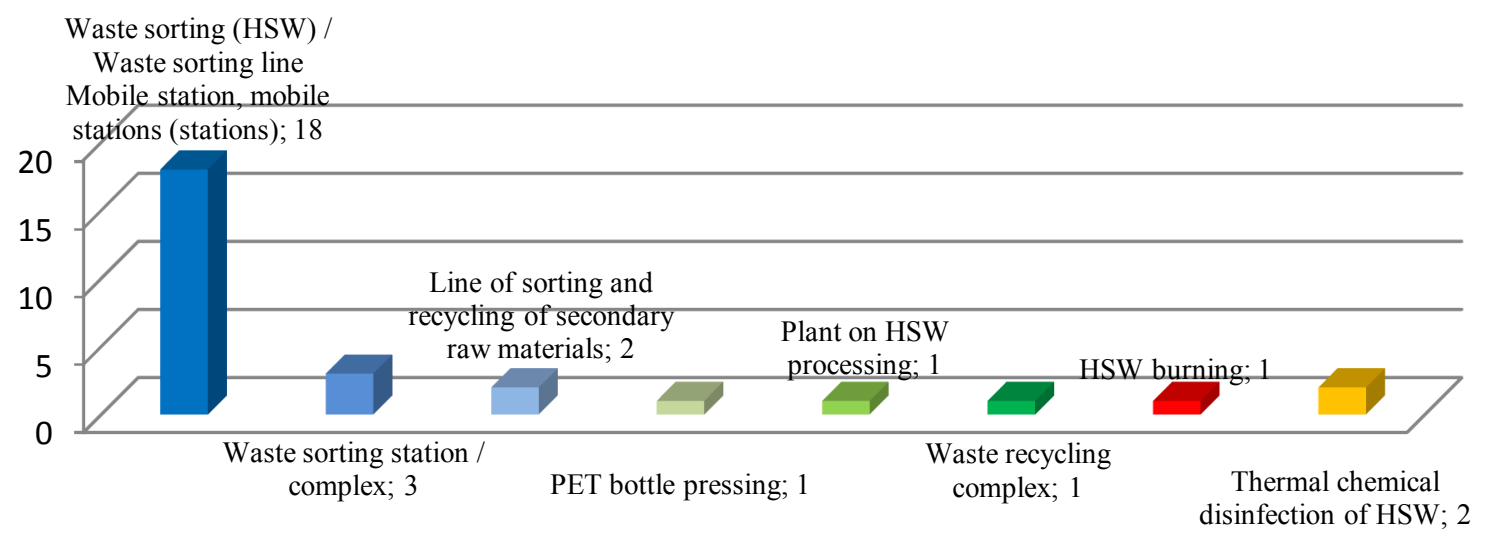

Fig. 5. Existing waste collection, waste recycling and incineration plants in Ukraine by the results of the $3 r d$ quarter of 2016, units of objects

Source: compiled based on [8].

EU member states, having realized not only the positive environmental aspects of such a process, but also the opportunity to profit from the activities of waste processing and waste incineration plants, at the legislative level created the preconditions for their successful and effective functioning: they decided to formulate a perfect system of separate collection of garbage; provided the maximum percentage of HSW, which are to be used as secondary raw materials; highlighted the smallest details of the functioning of the subjects of the sphere of treatment of household rubbish.

The EU's main regulatory framework for the management of all wastes is the Waste Framework Directive [20] (Directive 2006/12 / EC of the European Parliament and of the Council of 5 April 2006 on waste). Unlike the Law of Ukraine "On Waste", this normative legal act clearly covers the rules of waste management, their separate collection, processing, etc. The general requirement is to encourage the release by the EU Member States of environmentally friendly products that can be recycled. All EU waste management legislation is divided into the following: specific operations (e.g., Directive 2000/76 on Waste Incineration [19]); the handling of individual types of waste (e.g. Packaging Directive 94/62 [22], according to which EU member states should reduce the amount of packaging waste, introduce a wide system for processing such waste and create environmentally friendly products).

The EU's complete legislative framework, which details all aspects of HSW treatment in detail, laid the foundations for a well-established mechanism for the collection, transport and disposal of garbage. In accordance with Article 10 of the EU Waste Framework Directive, all the member states of the community have established a general requirement for separate collection of garbage with the obligation to set up separate collection systems for at least paper, metal, plastic and glass. Since the mechanism of such a process in the context of individual EU member states may differ, so they distinguish 5 types of systems for separate collection of litter (Fig. 6). 


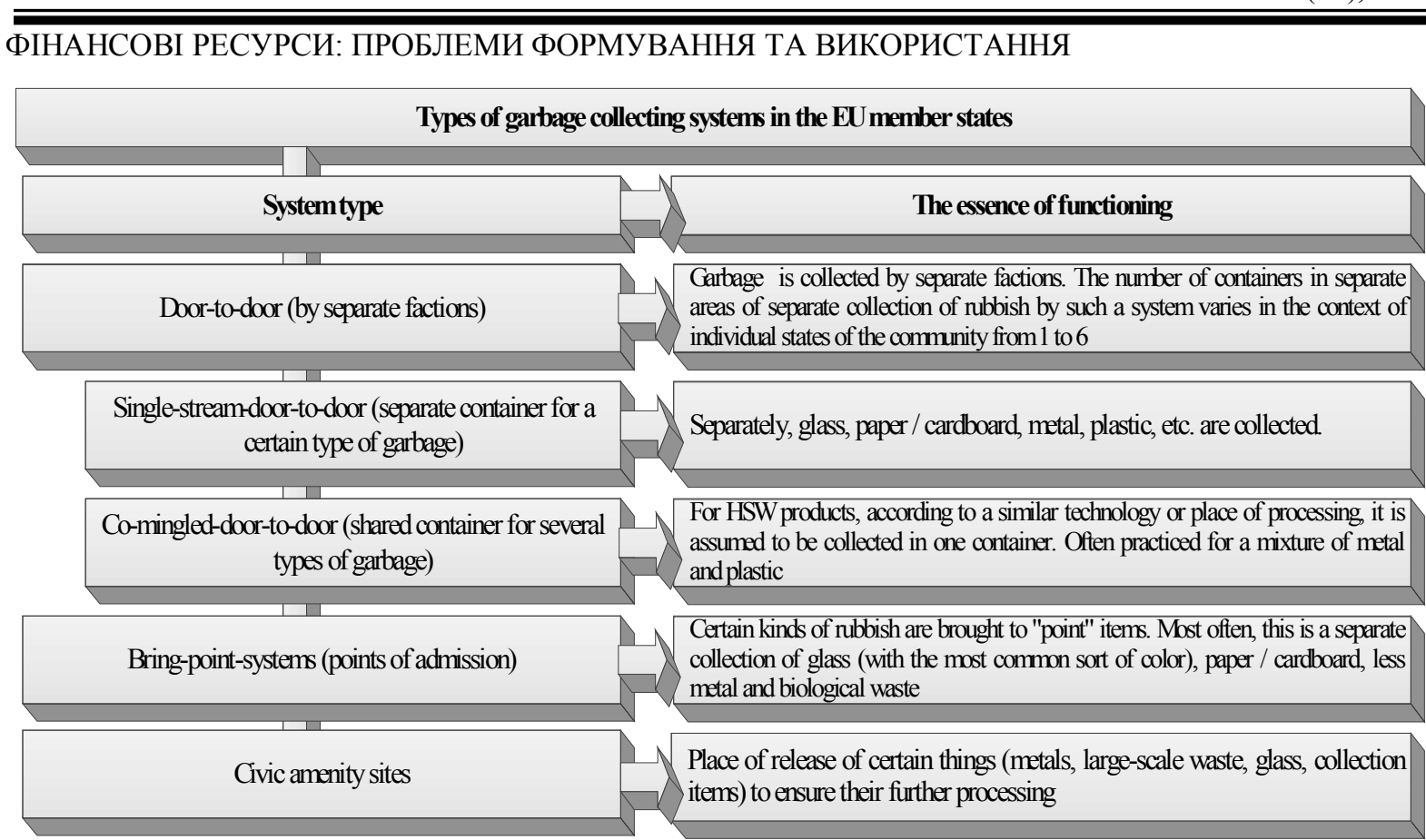

Fig. 6. The main types of separate HSW collecting in the EU

Source: compiled by the author based on [18].

The most common type of separate collection system of HSW is "Door-to-door". In the leading EU member states, garbage is sorted into separate containers for all types of waste listed in the Framework Directive; in others, the collection of several types of waste is practiced in one container (Fig. 7). In some countries (Germany, France, Luxembourg) utilization of metal and plastics is united geographically, sometimes - technologically, which justifies their joint collection. A common practice for providing a separate collection of glass and paper is the activity of the network of reception points for such waste. They are less likely to receive metal, plastic (only in Sweden) and biomaterials (Spain).

Separate garbage collection is a rather expensive pleasure both for the state and for its citizens. According to the Ministry of Regional Development, Construction and Housing and Communal Services of Ukraine, the cost of one container for the collection of solid waste products is about $3000 \mathrm{UAH}$. The creation of points of reception of certain types of garbage (the unbundled network available for metal and glass) will cost much more than the cost of equipping areas for separate garbage collection. Therefore, in an ideal case, such a platform should consist of at least 5 containers (for paper, glass, plastic + metal, biomass and mixtures of other wastes), which will require UAH 15,000. Obviously, the state and local budgets of Ukraine are not capable of ensuring the implementation of such a program. Actual is the search for additional sources of financing. 
ФІНАНСОВІ РЕСУРСИ: ПРОБЛЕМИ ФОРМУВАННЯ ТА ВИКОРИСТАННЯ
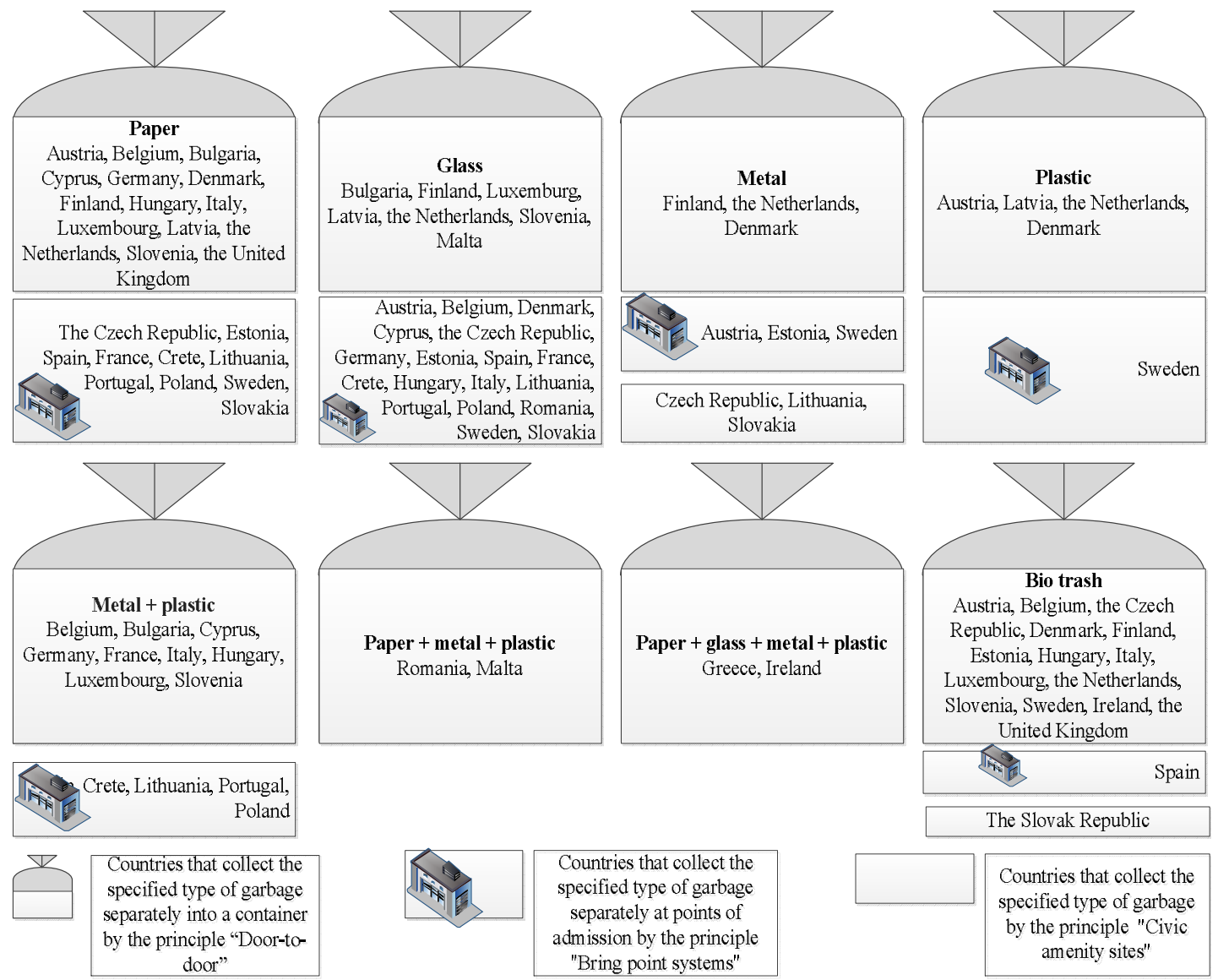

Czech Republic, Lithuania Slovakia
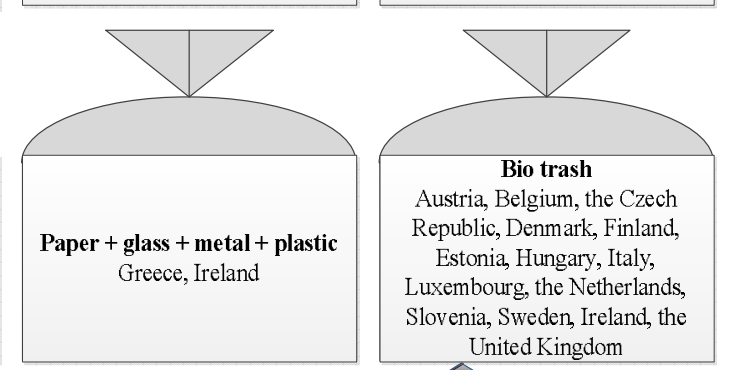

Austria, Belgium, the Czech Republic, Denmark, Finland, Estonia Hungary, Italy, Luxembourg, the Netherlands, Slovenia, Sweden, Ireland, the United Kingdom

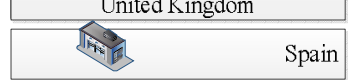

The Slovak Republic

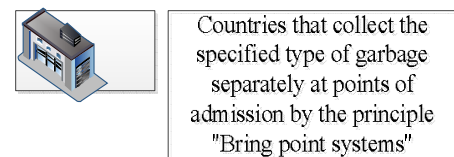

Countries that collect the specified type of garbage by the principle "Civic amenity sites"

Fig. 7. Separate garbage collection in the context of individual EU countries as of 2015

Source: complied based on [18].

Small amounts are received by citizens for receiving household waste services - about 54 UAH / cubic meter of garbage according to the results of 2016. Due to the fact that it is virtually impossible to trace the amount of garbage generated by each citizen (for this purpose it is necessary to organize an appropriate service, for example, as in Belgium), the fee does not correspond to the actual volumes.

Two ways to solve this problem are quite possible: the establishment of a fixed differentiated fee for separate and joint waste collection and the imposition of a tax on a number of products, which in principle predetermine the need for the sorting of HSW (in particular, in packages of plastic, glass, etc.). The first direction is based on the principle "for disposing of sorted garbage pay less", which is a fair and reliable way to increase financial revenues in order to form an effective mechanism for the treatment of HSW.

According to expert estimates, the EU family (2-3 people) averages 280 euros a year (more than 700 UAH per month) [2]. The average level of minimum wage for the available data for 2015 in the $21 \mathrm{EU}$ member states is approximately 823 euros per month [23], in Ukraine 111.11 euros [13]. That is, a reasonable fee for the Ukrainian family for the release of mixed domestic waste is 100-150 UAH / month. The garbage collector collects up to $75 \mathrm{~kg}$ per hour on average, earning a salary of up to $5000 \mathrm{UAH}$ per month [6]. Consequently, the defined tariff will cover the costs not only for the work of the sorter, but also for the transport of garbage.

For sorted rubbish in the EU, processors are paid for raw materials, for the population the same fee is symbolic. In the calculation for the Ukrainians - about $25 \mathrm{UAH} /$ month. For the release of mixed HSW at such a tariff, a penalty should be imposed at the legislative level (as in most EU member states), and an appropriate control service is organized, the role of which may at the initial stages be performed by the police. 
ФІНАНСОВІ РЕСУРСИ: ПРОБЛЕМИ ФОРМУВАННЯ ТА ВИКОРИСТАННЯ

Obligatory is the holding of thematic events: for example, hanging banners that would encourage the reporting of violations of such a law as a potential environmental hazard; sites with the publication of "eco-criminals", etc. In addition, most citizens, not wanting to sort the garbage, will be willing to pay at a specified rate, thereby stimulating the creation of new jobs by the vacancy of the "sorter". That is, this level of payment for services will fully cover the costs of separate deliveries of garbage to the corresponding processing points.

The second direction of attraction of additional funds for reformation of the sphere of HSW management is the introduction of a tax on a unit of certain types of products packaging (plastics, paper / cardboard, metal, glass). This method has been introduced in many EU member states: Denmark, France, Belgium, Norway, Finland, the Netherlands. The negative aspect of it is the expected inclusion of producers in the rate of the tax in the price of products. However, the fee will be low compared with the possible prospect of environmental protection, its clearing of garbage. For example, for Coca-Cola, 0.5 liters in plastic packaging will additionally have to pay 12.56 kopecks, for a drink with a volume of 0.33 liters in a glass - 11.34 kopecks, 0.25 liters in tin - 1, 93 kopecks, for juice in cardboard packaging $21-8.6$ kopecks. But the expected total income from the introduction of such a tax is quite significant - 6.44 billion UAH [15]. These funds will not only be enough to fully equip the sites for separate collection of rubbish throughout the territory of Ukraine, but also for the gradual creation of a network of waste sorting complexes. The cost of building a complex with a capacity of 20 thousand tons / year costs about 25 million UAH [8].

Taking into account the estimated need for waste sorting enterprises (about 500 objects), calculated on the basis of annually generated HSW, their network in the long term can be constructed in 2-3 years on the basis of tax on the specified products. In the future, such financial resources will contribute to the rapid improvement and development of the HSW treatment. Sorted rubbish is a valuable raw material for a number of EU member states (especially Sweden) for which they are willing to pay.

The structure of waste utilization processes in terms of material and energy conversion of HSW varies considerably in individual EU member states (Fig. 8), depending on historical aspects of the formation of the recycling system and financial priorities (for example, in Sweden, for a long time, a network of incinerators provides heating of residential buildings) .

Material utilization requires more money, but it fully meets the conditions for sustainable development, since energy reprocessing is controversial from an environmental point of view. Achievement of a high rate of waste disposal is not possible without the existence of a network of incinerators, since a significant part of household waste is not subject to material processing (more than 25\%). Therefore, in the leading countries in the HSW recycling, energy utilization is a widespread phenomenon. This is one of the reasons for the high rate of garbage incineration in Norway, the Netherlands, Denmark, Sweden, France, Austria, Switzerland, Belgium, Luxembourg, the United Kingdom, Germany, Italy (more than $40 \%$ of recycled waste products). In Ukraine, for the purpose of energy receiving, only $2.23 \%$ of the collected HSW are burned.

The high rate of HSW disposal in the EU member states is ensured by a well-established system of waste disposal facilities built on the basis of the population number (and garbage generated by it) and the area of the countries. According to expert estimates, Ukraine needs from 97 to 144 waste recycling plants. Taking into account that the cost of building a perfect, environmentally safe waste-processing complex with a capacity of 100 thousand tons / year reaches about 60 million dollars according to the Ministry of Regional Development, Construction and Housing and Communal Services of Ukraine, the network of such plants for Ukraine (based on the volume of rubbish annually) will cost from 6 to 10 billion dollars. USA [7; 8]. 


\section{ФІНАНСОВІ РЕСУРСИ: ПРОБЛЕМИ ФОРМУВАННЯ ТА ВИКОРИСТАННЯ}

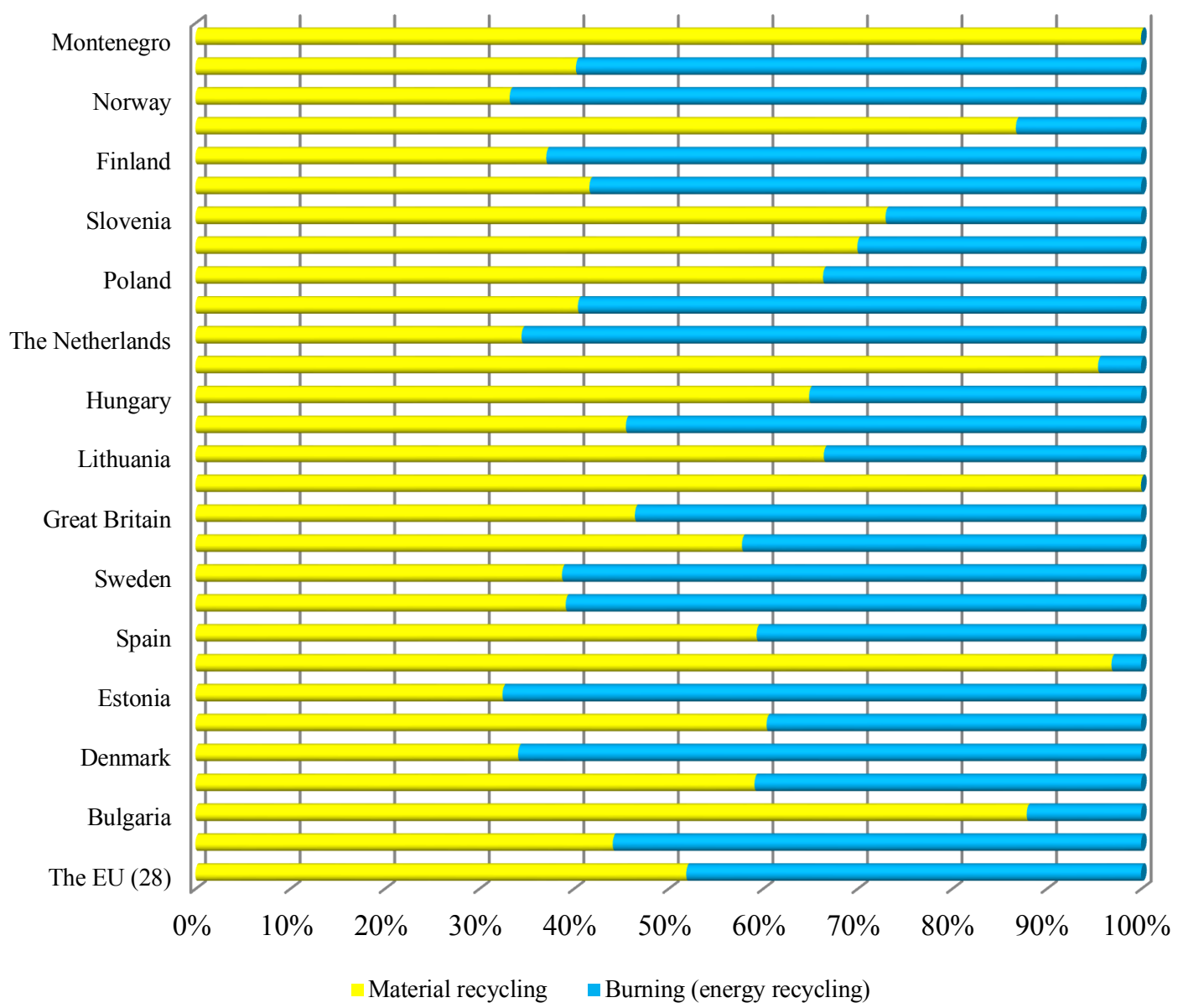

Fig. 8. The structure of recycling processes (recycling) in the context of individual EU member states as of 2015

Source: compiled based on [26].

Creation of a system of incineration plants for energy production in Ukraine can become a financially profitable solution to the environmental problem of household waste processing, which is basically no longer suitable for sorting or use as secondary raw materials.

The sale of thermal and electric energy will not only cover a significant part of the cost of building such complexes, but also save on the use of fossil fuels, especially natural gas for heating residential and commercial buildings. The payback period of such a project, despite obtaining a stable and sufficiently high profit, can reach 8 years, which makes business in this area unattractive for domestic investors.

Therefore, Ukraine's banking system, which has significant prospects for expanding its deposit base and boosting investment activity, can become the potential investor in this sector of the economy [5;28]. Conducting a substantiated set of tactical measures (settling the legislative framework on these issues, simplifying the procedure for investing by banks in the real sector of the economy, creating tax holidays or free economic zones, stimulating the development of financial and industrial groups, state support, etc.) will contribute to the achievement of the strategic goal of forming a network of utilization enterprises in our country. Similar programs for stimulating investment activity in the field of HSW management should be developed for other economic entities for the purpose of rapid and qualitative development of the industry.

In Ukraine, according to the results of 2016, 6089.5 thousand tons of HSW were officially removed (which according to the methodology of the State Statistics Service of Ukraine are not 
ФІНАНСОВІ РЕСУРСИ: ПРОБЛЕМИ ФОРМУВАННЯ ТА ВИКОРИСТАННЯ

subject to utilization), which makes $52.67 \%$ of their total volume, of which $69.1 \%$ are transported to specially equipped landfill. Currently, in our state there are 6,500 authorized dumps; the number of natural garbage dumps is more than 5 times the number of legal ones, which is largely due to the inaccessibility of services for the export of HSW to almost $22 \%$ of the population (especially rural). According to expert estimates, the total area of landfills is about $7 \%$ of the territory of Ukraine, with the urgent problem of a steady increase in their number [11].

In the leading EU countries, the existence of landfills is considered to be almost a catastrophe. After all, the life of a highly developed society is incompatible with harmful vapors of HSW, the penetration of bacteria into underground water and the existence of a heap of rubbish on the territory, which can be used more profitably in general. In the leading EU countries, most garbage is subject to utilization and burning, and transportation to landfill is only a small part (Fig. 9).

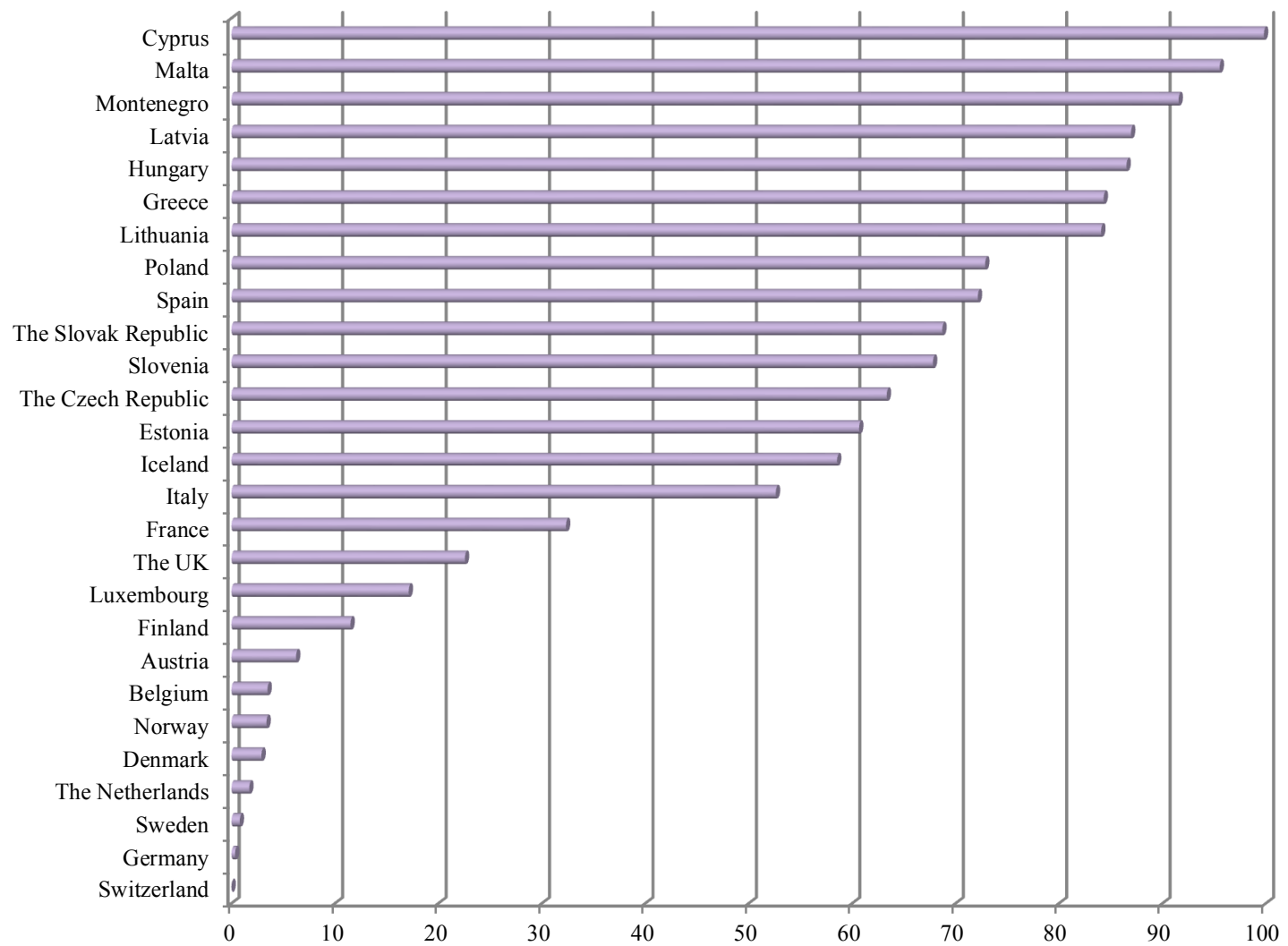

Fig. 9. Share of municipal waste generated by EU countries, buried in landfills in $2015, \%$ Source: compiled based on [24].

If in Ukraine under the rubbish landfill site is mainly meant a simply-equipped, more or less remote territory, then in the EU member states (besides the newly integrated ones) this term is understood as a complex engineering structure that guarantees complete sanitary safety of the population. If the polygon is filled with the estimated amount of garbage, it is isolated in such a way that even the construction of recreational zones in these sites is possible. But even reaching the technical and technological excellence of the facility, only $25.59 \%$ of the HSW in 2015 was buried at the landfills [24].

The reason for the existence of a huge amount of landfills in Ukraine is not only the lack of utilization enterprises, but also the tariff policy of the state: the cost of transporting garbage to the landfill is lower than the cost of its burning; for the illegal landfill, the difference is particularly noticeable - 2.5 times. The charge for HSW burying in Ukraine is negligible compared to the EU member states, while these funds could be aimed at creating a proper recycling system in our country. 
ФІНАНСОВІ РЕСУРСИ: ПРОБЛЕМИ ФОРМУВАННЯ ТА ВИКОРИСТАННЯ

That is, the HSW treatment should be based on a model that would provide the smallest amount of their transportation to landfills and disposal at landfills (Fig. 10).

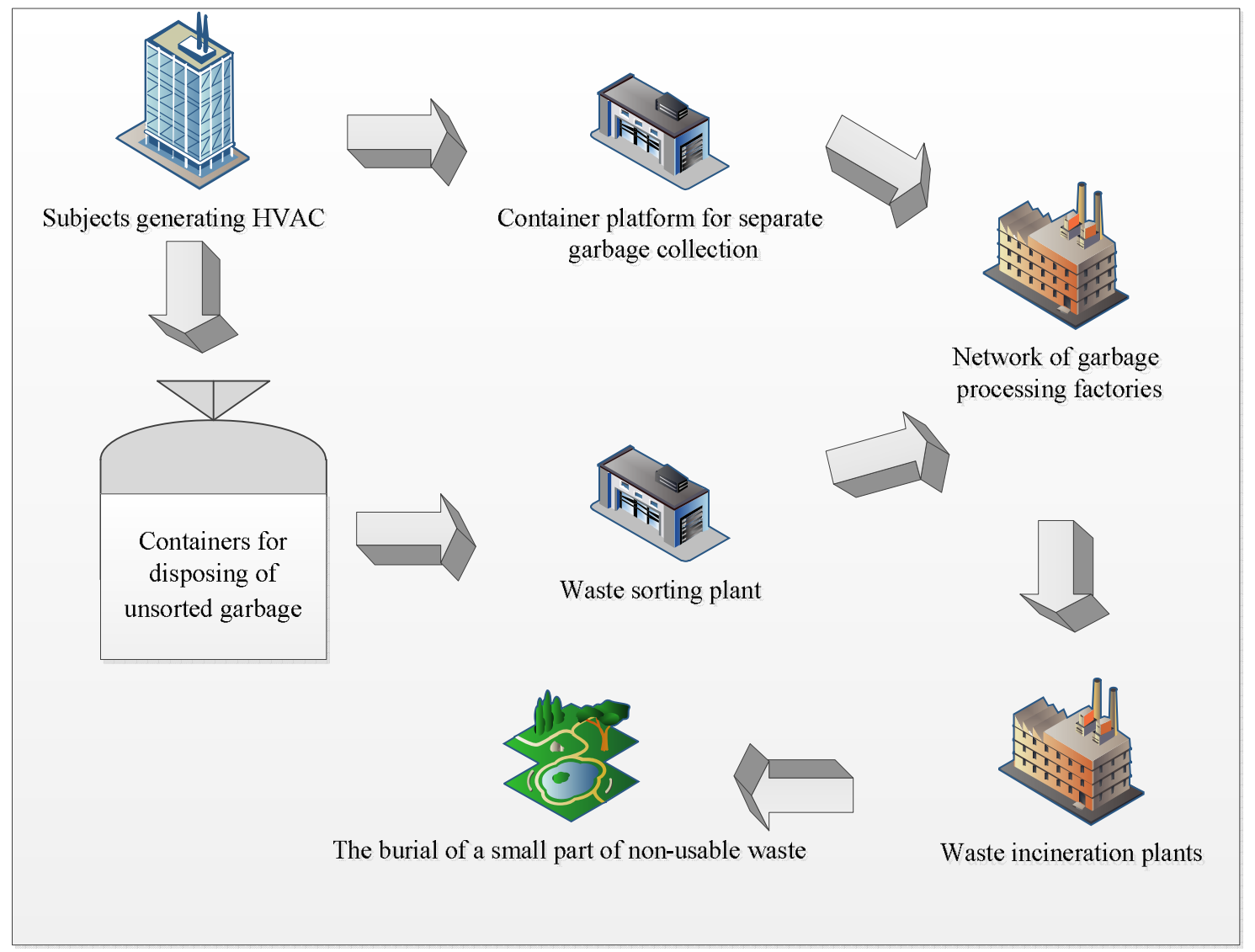

Source: compiled by the authors.

Fig. 10. Optimum cycle of HSW handling

A rather important aspect for implementation of the given model of waste management is that each region of Ukraine should intensify this process. Now, due to financial decentralization and the availability of local budgets, every region of Ukraine should take the initiative and start implementation of waste management projects.

An example of regional activity can be found in Lviv, where the European Bank for Reconstruction and Development [4] is scheduled to start the rehabilitation of Gribovitsky landfill and the construction of a plant for mechanical and biological processing of garbage.

Conclusions and propositions. The conducted researches show that in Ukraine the handling of household and similar waste (HSW) is low and has a large number of unresolved problems. The tendency of constant growth in the country's volumes of HSW is obvious, and the system of their utilization is practically absent. Therefore, comprehensive diagnostics of the peculiarities of the operation of waste management in the developed countries of the world is a necessary factor for the development of recommendations for the reformation of the existing system of utilization of HSW treatment plants in Ukraine.

The experience of the EU member states, due to which it became possible to create a wellestablished mechanism for separate collection of waste, material and energy recycling, and environmentally safe disposal at well-designed landfills, has been considered, it allows us to choose ways of reforming the system of HSW treatment in Ukraine. To modernize this industry, a well-founded strategic project is needed that will require substantial financial resources, but this will enable us to create environmental, social and financial perspectives for our country. Such a transformation will not only significantly accelerate the integration processes of Ukraine into the EU, but will also lead the country to a new socio-economic level of development. 
ФІНАНСОВІ РЕСУРСИ: ПРОБЛЕМИ ФОРМУВАННЯ ТА ВИКОРИСТАННЯ

\section{References}

1. Abramova, M. V. \& Osmanov, I. H. (2011). Formuvannia ratsionalnoi systemy upravlinnia tverdymy pobutovymy vidkhodamy [Formation of a rational system of management of solid household waste]. Visnyk ekonomichnoi nauky Ukrainy - Bulletin of economic science of Ukraine, 2, 6-10 [in Ukrainian].

2. Aratovska, Ye. (2017). Kto zaplatit za musor? [Who will pay for trash?]. Retrieved from http://life.pravda.com.ua/columns/2017/05/30/224436.

3. Grabovsky, R. S., Dorosh, M. M. \& Dudyak, R. P. (2014). Rehionalna systema zboru ta pererobky smittya yak sposib vyrishennya ekoloho-ekonomichnykh problem [Regional system of garbage collection and processing as a way of solving environmental and economic problems]. Naukovyy visnyk LNUVMBT - Scientific Bulletin of LNUWMBT, 2 (59), 66-70 [in Ukrainian].

4. YeBRR vydilyt $€ 35$ milioniv na smittiepererobnyi zavod u Lvovi [EBRD will allocate $€ 35$ million to a waste recycling plant in Lviv]. Retrieved from http://www.pravda.com.ua/news/ 2017/09/3/7153917.

5. Zharii, Ya. \& Krasnianska, Yu. (2017). Transformuvannia investytsiynoi diialnosti bankivskoi systemy Ukrainy dlia realizatsii stratehichnykh proektiv [Transformation of investment activity of the banking system of Ukraine for the implementation of strategic projects]. Problemy i perspektyvy ekonomiky ta upravlinnya - Problems and prospects of economics and management, 3 (11), 125-134 [in Ukrainian].

6. Zarplata sortuvalnyka [Salary of the sorter]. Retrieved from http://mojazarplata.com.ua/ ua/main/zarobitok/kalqkuljator-zarplati?job-id=9612010000000\#.

7. Ignatenko, O. P. (2012). Pobutovi vidkhody - pravyla hry na rynku. Praktychnyy posibnyk [Domestic waste - the rules of the game on the market: practical guide]. Kyiv: Modern writer [in Ukrainian].

8. Informatsiia shchodo vprovadzhennia suchasnykh metodiv ta tekhnolohii u sferi povodzhennia z pobutovymy vidkhodamy stanom na 01.09.2016 roku [Information on the implementation of modern methods and technologies in the field of household waste management from September 1, 2016]. Ministerstvo rehionalnoho rozvytku, budivnytstva ta zhytlovo-komunalnoho hospodarstva Ukrainy Ministry of Regional Development, Construction and Housing and Communal Services of Ukraine. Retrieved from http://www.minregion.gov.ua/napryamki-diyalnosti/zhkh/terretory/informatsiyashhodo-vprovadzhennya-suchasnih-metodiv-ta-tehnologiy-u-sferi-povodzhennya-z-pobutovimividhodami -stanom-na-01-09-2016-roku.

9. Kilkist administratyvno-terytorialnykh odynyts za rehionamy Ukrainy na 1 sichnia 2016 roku [Number of administrative-territorial units by regions of Ukraine from January 1, 2016]. Derzhavna sluzhba statystyky Ukrayiny - State Statistics Service of Ukraine. Retrieved from http://www.ukrstat.gov.ua/operativ/operativ2016/ds/ator/ator2016 u.htm.

10. Kryvenko, S. V. (2015). Problemy vdoskonalennia systemy upravlinnia sferoiu povodzhennia $\mathrm{z}$ tverdymy pobutovymy vidkhodamy: rehionalnyi aspekt [Problems of improving the control system of the sphere of solid household waste management: the regional aspect]. Upravlinnia rozvytkom Development management, 2, 12-19 [in Ukrainian].

11. Natsionalnyi forum «Povodzhennia $z$ vidkhodamy v Ukraini: zakonodavstvo, ekonomika, tekhnolohii» [National Forum «Waste Management in Ukraine: legislation, economics, technologies»]. Retrieved from http://vidhody.org.ua/news/view/24-06-2016-pererobka-smittya-vukraini-ta-s-yak-ekologichnu-katastrofu-perevesti-u-pributkoviy-biznes.

12. Pohribnyi, I. Ya. (2013). Do pytannia systemnoho povodzhennia z tverdymy pobutovymy vidkhodamy [On the issue of systemic treatment of solid household waste]. Efektyvna ekonomika Effective economy, 1. Retrieved from http://www.economy.nayka.com.ua/?op=1\&z=1709.

13. Pokaznyky valyutnoho rynku [Indicators of the foreign exchange market]. $N B U-N B U$. Retrieved from https://bank.gov.ua/control/uk/publish/category?cat_id=7693080.

14. Poltavets, S. \& Beregelsky, A. (2015). Problemy utylizatsii vidkhodiv v Ukraini [Problems of waste utilization in Ukraine]. Tsentr doslidzhen sotsialnykh komunikatsiy NBUV-Center for Social Communications Studies of NBUV. Retrieved from http://nbuviap.gov.ua/index.php?option= com_content\&view $=$ article $\&$ id $=900 \% 3$ Autilizatsiya-smittya $\&$ catid $=8 \&$ Itemid $=350$. 
ФІНАНСОВІ РЕСУРСИ: ПРОБЛЕМИ ФОРМУВАННЯ ТА ВИКОРИСТАННЯ

15. Spetsproekt Liga.net «Musornye milliony» [Special project Liga.net «Trash millions»]. Retrieved from http://www.liga.net/projects/musornie_millioni.

16. Kharchenko, T. \& Sahaydak, Yu. (2014). Udoskonalennia systemy pererobky tverdykh pobutovykh vidkhodiv v Ukraini [Improvement of the system of solid waste recycling in Ukraine]. Visnyk Kyivskoho natsionalnoho universytetu im. T. Shevchenka - Bulletin of the Kyiv National University named after T. Shevchenko, 12 (165), 41-46 [in Ukrainian].

17. Shylovych, T. B., Sas, A. S. (2014). Problemy stanu zakonodavstva Ukrainy pro povodzhennia $z$ vidkhodamy [Problems of the legislation of Ukraine on waste management]. Retrieved from http://cpsm.kpi.ua/publikatsiji/tezi/1154-problema-stanu-zakonodavstva-ukrajini-pro-povodzhennya-zvidkhodami.html.

18. Assessment of separate collection schemes in the 28 capitals of the EU (2015). Retrieved from http://ec.europa.eu/environment/waste/studies/index.htm.

19. Directive 2000/76/EC, incineration of waste. Retrieved from https://www.eea.europa.eu/ policy-documents/directive-2000-76-ec-incineration.

20. Directive 2006/12/EC of the European Parliament and of the Council. Retrieved from http://eur-lex.europa.eu/legal-content/EN/TXT/?uri=CELEX:32006L0012.

21. Husaini, I. G., Garg, A., Kim, K. H., Marchant, J., Pollard, S. J. T. \& Smith, R. (2007). European household waste management schemes: Their effectiveness and applicability in England. Resources, Conservation and Recycling, 51, 248-263. Retrieved from https://www.sciencedirect.com/ science/journal/09213449/51/1.

22. European Parliament and Council Directive 94/62/EC of 20 December 1994 on packaging and packaging waste. Retrieved from http://eur-lex.europa.eu/legal-content/EN/TXT/?uri= CELEX:01994L0062-20150526.

23. Minimum wages. Eurostat. Retrieved from http://ec.europa.eu/eurostat/tgm/ table.do?tab=table\&init $=1 \&$ language $=$ en $\&$ pcode $=$ tps $00155 \&$ plugin $=1$.

24. Municipal waste by waste operations. Eurostat. Retrieved from http://appsso.eurostat.ec.europa.eu/nui/submitViewTableAction.do.

25. Municipal waste generated by country in selected years ( $\mathrm{kg}$ per capita). Eurostat. Retrieved from http://ec.europa.eu/eurostat/statistics-explained/images/f/fe/Municipal_waste_generated_by_country_in selected_years_\%28kg_per_capita\%29.png.

26. Municipal waste generation and treatment, by type of treatment method. Eurostat. Retrieved from $\mathrm{http}: /$ ec.europa.eu/eurostat/tgm/table.do?tab=table\&init=1\&language $=$ en\& pcode=tsdpc240\&plugin=1.

27. Recycling rate of municipal waste. Eurostat. Retrieved from http://ec.europa.eu/eurostat/tgm/table.do?tab=table\&init=1\&language=en\&pcode=t2020_rt120\&plugin=1.

28. Zharii, Ya. \& Krasnianska, Yu. (2017). Problems and prospects of modernization of the deposit base of the banking system of Ukraine. Problems and prospects of economics and management, 2 (10), 160-170 [in Ukrainian].

\section{Список використаних джерел}

1. Абрамова М. В., Османов I. Х. Формування раціональної системи управління твердими побутовими відходами. Вісник економічної науки Украӥни. 2011. № 2 (20). С. 6-10.

2. Аратовська Є. Кто заплатит за мусор? URL: http://life.pravda.com.ua/columns/ 2017/05/30/224436 (дата обращения: 21.04.2018).

3. Грабовський Р. С., Дорош М. М., Дудяк Р. П. Регіональна система збору та переробки сміття як спосіб вирішення еколого-економічних проблем. Науковий вісник ЛНУВМБТ. 2014. № 2 (59). С. 66-70.

4. ЄБРР виділить $€ 35$ мільйонів на сміттєпереробний завод у Львові. URL: http://www.pravda.com.ua/news/2017/09/3/7153917 (дата звернення: 11.04.2018).

5. Жарій Я., Краснянська Ю. Трансформування інвестиційної діяльності банківської системи України для реалізації стратегічних проектів. Проблеми і перспективи економіки та уnравління. 2017. № 3 (11). С. 125-134.

6. Зарплата сортувальника URL: http://mojazarplata.com.ua/ua/main/zarobitok/kalqkuljatorzarplati?job-id=9612010000000\# (дата звернення: 13.04.2018). 
ФІНАНСОВІ РЕСУРСИ: ПРОБЛЕМИ ФОРМУВАННЯ ТА ВИКОРИСТАННЯ

7. Ігнатенко О. П. Побутові відходи - правила гри на ринку: практичний посібник. Київ: ПП «Сучасний письменник», 2012. 160 с.

8. Інформація щодо впровадження сучасних методів та технологій у сфері поводження 3 побутовими відходами станом на 01.09.2016 року / Міністерство регіонального розвитку, будівництва та житлово-комунального господарства України. URL: http://www.minregion.gov.ua/ napryamki-diyalnosti/zhkh/terretory/informatsiya-shhodo-vprovadzhennya-suchasnih-metodiv-tatehnologiy-u-sferi-povodzhennya-z-pobutovimi-vidhodami-stanom-na-01-09-2016-roku (дата звернення: 11.03.2018).

9. Кількість адміністративно-територіальних одиниць за регіонами України на 1 січня 2016 року / Державна служба статистики України. URL: http://www.ukrstat.gov.ua/operativ/ operativ2016/ds/ator/ator2016_u.htm (дата звернення: 22.03.2018).

10. Кривенко С. В. Проблеми вдосконалення системи управління сферою поводження 3 твердими побутовими відходами: регіональний аспект. Управління розвитком. 2015. № 2. С. 12-19.

11. Національний форум «Поводження з відходами в Україні: законодавство, економіка, технології» URL: http://vidhody.org.ua/news/view/24-06-2016-pererobka-smittya-v-ukraini-ta-s-yakekologichnu-katastrofu-perevesti-u-pributkoviy-biznes (дата звернення: 01.03.2018).

12. Погрібний I. Я. До питання системного поводження з твердими побутовими відходами. Ефективна економіка. 2013. № 1. URL: http://www.economy.nayka.com.ua/?op=1\&z=1709 (дата звернення: 03.03.2018).

13. Показники валютного ринку / НБУ. URL: https://bank.gov.ua/control/uk/publish/ category?cat_id=7693080 (дата звернення 05.04.2018).

14. Полтавець С., Берегельський А. Проблеми утилізації відходів в Україні. URL: http://nbuviap.gov.ua/index.php?option=com_content\&view=article\&id=900\%3Autilizatsiyasmittya\&catid=8\&Itemid=350 (дата звернення: 11.04 .2018 ).

15. Спецпроект Liga.net «Мусорные миллионы» URL: http://www.liga.net/projects/ musornie_millioni (дата звернення: 10.04.2018).

16. Харченко Т., Сагайдак Ю. Удосконалення системи переробки твердих побутових відходів в Україні. Вісник Київського начіонального університету ім. Т. Шевченка. 2014. № 12 (165). С. 41-46.

17. Шилович Т. Б., Сас А. С. Проблеми стану законодавства України про поводження з відходами. URL: http://cpsm.kpi.ua/publikatsiji/tezi/1154-problema-stanu-zakonodavstva-ukrajini-propovodzh ennya-z-vidkhodami.html (дата звернення: 03.05.2018).

18. Assessment of separate collection schemes in the 28 capitals of the EU. Final Report. URL: http://ec.europa.eu/environment/waste/studies/index.htm (Last accessed: 17.03.2018).

19. Directive 2000/76/EC, incineration of waste. URL: https://www.eea.europa.eu/policydocuments/directive-2000-76-ec-incineration (Last accessed: 11.04.2018).

20. Directive 2006/12/EC of the European Parliament and of the Council. URL: http://eurlex.europa.eu/legal-content/EN/TXT/?uri=CELEX:32006L0012 (Last accessed: 11.04.2018).

21. Husaini I. G., Garg A., Kim K. H., Marchant J., Pollard S. J. T., Smith R. European household waste management schemes: Their effectiveness and applicability in England. Resources, Conservation and Recycling. 2007. № 51. Pp. 248-263.

22. European Parliament and Council Directive 94/62/EC of 20 December 1994 on packaging and packaging waste. URL: http://eur-lex.europa.eu/legal-content/EN/TXT/?uri=CELEX:01994L006220150526 (Last accessed: 11.04.2018).

23. Minimum wages / Eurostat. URL: http://ec.europa.eu/eurostat/tgm/table.do?tab=table\&init= 1\&language $=$ en\&pcode $=$ tps00155\&plugin $=1$ (Last accessed: 23.04.2018).

24. Municipal waste by waste operations / Eurostat. URL: http://appsso.eurostat.ec.europa.eu/nui/ submitViewTableAction.do (Last accessed: 23.04.2018).

25. Municipal waste generated by country in selected years (kg per capita) / Eurostat. URL: http://ec.europa.eu/eurostat/statistics-explained/images/f/fe/Municipal_waste_generated_by_ country_in_selected_years_\%28kg_per_capita\%29.png (Last accessed: 11.03.2018).

26. Municipal waste generation and treatment, by type of treatment method / Eurostat. URL: $\mathrm{http}: / /$ ec.europa.eu/eurostat/tgm/table.do?tab=table\&init=1\&language $=$ en\&pcode $=$ tsdpc240\&plugin $=1$ (Last accessed: 11.03.2018). 
ФІНАНСОВІ РЕСУРСИ: ПРОБЛЕМИ ФОРМУВАННЯ ТА ВИКОРИСТАННЯ

27. Recycling rate of municipal waste / Eurostat. URL: http://ec.europa.eu/eurostat/tgm/ table.do?tab=table\&init=1\&language $=$ en\&pcode=t2020 rt120\&plugin=1 (Last accessed: 11.04.2018).

28. Zharii Ya., Krasnianska Yu. Problems and prospects of modernization of the deposit base of the banking system of Ukraine. Problems and prospects of economics and management. 2017. № 2 (10). P. 160-170.

Zharii Yadviga - PhD in Technical Sciences, Associate Professor, Associate Professor of Department of Finance, Banking and Insurance, Chernihiv National University of Technology (95 Shevchenka Str., 14035 Chernihiv, Ukraine).

Жарій Ядвіга Вікентіївна - кандидат технічних наук, доцент, доцент кафедри фінансово-економічної безпеки, Чернігівський національний технологічний університет (вул. Шевченка, 95, м. Чернігів, 14035, Україна).

Жарий Ядвига Викентьевна - кандидат технических наук, доцент, доцент кафедры финансовоэкономической безопасности, Черниговский национальный технологический университет (ул. Шевченко, 95, г. Чернигов, 14035, Украина).

E-mail: yavizhar@gmail.com

Krasnianska Yuliia - student, Chernihiv National University of Technology (95 Shevchenka Str., 14035 Chernihiv, Ukraine).

Краснянська Юлія Валеріївна - студентка, Чернігівський національний технологічний університет (вул. Шевченка, 95, м. Чернігів, 14035, Україна).

Краснянская Юлия Валерьевна - студентка, Черниговский национальный технологический университет (ул. Шевченко, 95, г. Чернигов, 14035, Украина).

E-mail: krasnyanskaya.yulia@gmail.com 